Reprinted from 99 Columbia L. Rev. (1999). Copyright Jack M. Balkin 1999. All rights reserved.

\title{
FREE SPEECH AND HOSTILE ENVIRONMENTS
}

\author{
J.M. Balkin*
}

One major concern about sexual harassment law is that employers will restrict employee speech in order to avoid hostile environment liability, thus violating free speech principles. In this Essay, Professor Balkin argues that this "collateral censorship" is constitutionally permissible when there are good grounds for vicarious liability. Because employers actively control workplace culture, and because they are better able to prevent hostile environments than individual employees, vicarious liability for employee speech is more justified than in the case of distributors or common carriers.

Professor Balkin also argues that captive audience doctrine, generally thought to apply only to speech in the home, is actually better suited to workplace speech. Hostile environments are a method of sex discrimination that maintains gender segregation; a hostile environment does its work precisely through making the employee a captive audience.

The Essay concludes that First Amendment challenges to sexual harassment law should not become a defense of employer prerogatives presented in the guise of worker liberties. Without the incentives created by sexual harassment law, employees will not be freed from censorship; they will simply be remitted to the economic and social control of employers.

Does sexual harassment law conflict with the First Amendment? A number of commentators now argue that it does. ${ }^{1}$ Generally, these

\footnotetext{
* Knight Professor of Constitutional Law and the First Amendment, Yale Law School. My thanks to Bruce Ackerman, Akhil Amar, Ian Ayres, Dan Kahan, Sandy Levinson, Vicki Schultz, Reva Siegel, and Eugene Volokh for their comments on previous drafts.

1. See, e.g., Kingsley R. Browne, Title VII as Censorship: Hostile-Environment Harassment and the First Amendment, 52 Ohio St. L.J. 481, 548 (1991) [hereinafter Browne, Title VII as Censorship]; Kingsley R. Browne, Workplace Censorship: A Response to Professor Sangree, 47 Rutgers L. Rev. 579, 580-85 (1995); Jules B. Gerard, The First Amendment in a Hostile Environment: A Primer on Free Speech and Sexual Harassment, 68 Notre Dame L. Rev. 1003, 1033-34 (1993); Eugene Volokh, Freedom of Speech and Workplace Harassment, 39 UCLA L. Rev. 1791, 1846 (1992) [hereinafter Volokh, Freedom of Speech]; Eugene Volokh, How Harassment Law Restricts Free Speech, 47 Rutgers L. Rev. 563, 567 (1995) [hereinafter Volokh, How Harassment]; Eugene Volokh, What Speech Does "Hostile Work Environment"
} 
objections focus on employer liability for speech by employers and employees that creates hostile environments. Virtually no one finds fault with regulating quid pro quo sexual harassment: Employers who tell employees "sleep with me or you're fired" make threats that are not protected by the First Amendment. ${ }^{2}$ In this Essay I offer an account of why hostile environment doctrine, properly interpreted, does not violate freedom of speech. ${ }^{3}$ I address two basic kinds of objections. The first concedes that the creation of a hostile environment is not protected speech, but argues that fear of Title VII liability will lead employers to censor employee speech and that this chilling effect violates the First Amendment. ${ }^{4}$ I hope to show why these concerns are overstated through a discussion of the idea of collateral censorship — an important but largely overlooked concept in the theory of free speech. Collateral censorship occurs when $A$ censors $B$ out of fear that the government will hold $A$ liable for the effects of $B$ 's speech. I believe that the question of when collateral censorship is a permissible effect of regulation and when it is unconstitutional will be increasingly important in the law of telecommunications and cyberspace. In this case, however, the concept of collateral censorship helps us understand the constitutionality of hostile environment law.

The second, and more radical attack on hostile environment liability argues that when employers create a hostile environment that materially alters working conditions to the disadvantage of women and minorities, they are engaged in protected speech. ${ }^{5}$ Rebutting this more radical attack helps us understand another important but undertheorized category in First Amendment law-

Harassment Law Restrict?, 85 Geo. L.J. 627, 647 (1997) [hereinafter Volokh, What Speech].

2. See, e.g., Nadine Strossen, The Tensions Between Regulating Workplace Harassment and the First Amendment: No Trump, 71 Chi.-Kent L. Rev. 701, 704 (1995) ("Even the most diehard free speech absolutist recognizes that the speech involved in quid pro quo harassment is tantamount to threats or extortion."); Volokh, Freedom of Speech, supra note 1, at 1800 (quid pro quo harassment is no more protected than "any other form of threat or extortion").

3. In this Essay I shall primarily be concerned with sexual harassment, and, to a lesser extent, racial harassment. I do not discuss religious harassment. I think that accusations of religious harassment often raise distinctive problems. For example, some employees might object to proselytization by co-workers or provocative displays of religious paraphernalia. Although both of these can undoubtedly make workers feel uncomfortable, neither is the precise equivalent of racist and sexist speech designed to drive blacks and women from the workplace. The rules that govern these situations must be tailored to take these differences into account.

4. See, e.g., Browne, Title VII as Censorship, supra note 1, at 505, 510-13, 548; Volokh, Freedom of Speech, supra note 1, at 1809-14; Volokh, What Speech, supra note 1, at 635-37.

5. See, e.g., Browne, Title VII as Censorship, supra note 1, at 544-47. For related reasons, Eugene Volokh argues that hostile environment law should be limited to face-to-face verbal harassment directed at particular individuals. See Volokh, Freedom of Speech, supra note 1, at 1846. This implies that other forms of communicative harassment, even if they materially alter working conditions to the disadvantage of women and minorities, are protected speech and may not be limited on the basis of content, viewpoint, or subject matter. See id. at 1849. 
captive audience doctrine. It also helps connect the captive audience doctrine more closely to what I regard to be the deeper purposes of antidiscrimination law.

\section{Collateral CENSORShiP}

Although threats are not protected by the First Amendment, hostile environments do not always involve threats. A hostile environment is made up of individual acts of discriminatory speech and other conduct by all the persons who inhabit a workplace, including managers, employees, and even occasionally clients and customers. In hostile environments, "the workplace is permeated with 'discriminatory intimidation, ridicule, and insult' that is 'sufficiently severe or pervasive to alter the conditions of the victim's employment and create an abusive working environment...." 6 Some of this behavior may be directed at particular employees; other elements may be directed at no one in particular but may help foster an abusive environment. Even if individual acts do not constitute a hostile environment separately, they can be actionable when taken together. The test is whether the conduct, taken as a whole, would lead to an environment that the employee reasonably perceives as abusive. ${ }^{7}$

Employers can be liable for maintaining a hostile work environment even if management did not personally engage in any of the predicate acts. In Burlington Industries, Inc. v. Ellerth ${ }^{8}$ and Faragher v. City of Boca Raton, ${ }^{9}$ the Supreme Court held that employers are liable for harassment by supervisory personnel, subject to a number of affirmative defenses where the harassment did not result in a tangible employment action like firing or demotion. ${ }^{10}$

6. Harris v. Forklift Sys., Inc., 510 U.S. 17, 21 (1993) (quoting Meritor Sav. Bank v. Vinson, 477 U.S. 57, 65, 67 (1986)).

7. See Harris, 510 U.S. at 21-23.

8. 524 U.S. 742 (1998).

9. 524 U.S. 775 (1998).

10. The Supreme Court's current doctrine is that

[a]n employer is subject to vicarious liability to a victimized employee for an actionable hostile environment created by a supervisor with immediate (or successively higher) authority over the employee. When no tangible employment action is taken, a defending employer may raise an affirmative defense to liability or damages, subject to proof by a preponderance of the evidence. The defense comprises two necessary elements: (a) that the employer exercised reasonable care to prevent and correct promptly any sexually harassing behavior, and (b) that the plaintiff employee unreasonably failed to take advantage of any preventive or corrective opportunities provided by the employer or to avoid harm otherwise. While proof that an employer had promulgated an anti-harassment policy with complaint procedure is not necessary in every instance as a matter of law, the need for a stated policy suitable to the employment circumstances may appropriately be addressed in any case when litigating the first element of the defense. And while proof that an employee failed to fulfill the corresponding obligation of reasonable care to avoid harm is not limited to showing any 
The degree of vicarious liability for non-supervisory personnel (such as co-workers) is still contested, but currently most courts hold an employer liable if the employer knew or should have known of the harassment and did not take prompt corrective action. ${ }^{11}$

Employers who want to minimize hostile environment liability cannot merely prohibit individual instances of harassing conduct. They must also limit conduct that might, in combination with other conduct, contribute to a hostile environment. Hence employers are tempted to create prophylactic rules against all the potential components of a hostile environment. Some of these will be unwelcome physical advances, assaults, and forms of abuse. Others will be largely verbal: sexual jokes and innuendoes, taunts and threats, sexually oriented cartoons, pictures, and pornography. Some of this verbal abuse may even be couched in political or factual terms; for example, co-workers might oppose affirmative action programs for women or quote scientific studies arguing that women are less competent at certain jobs. Because employers have no general interest in preserving employee speech rights unrelated to efficiency, they will impose regulations as broad as they think necessary to insulate themselves from liability. ${ }^{12}$ The most important complaints about the constitutionality of sexual harassment law stem from these incentives to censor employee speech that might contribute to a hostile environment. ${ }^{13}$

The argument that sexual harassment law produces unconstitutional employee censorship is actually an instance of a more general problem in free speech law-a phenomenon I call collateral censorship. ${ }^{14}$ Collateral censorship occurs when one private party $A$ has the power to control speech by another private party $B$, the government threatens to hold $A$ liable based on what $B$ says, and $A$ then censors $B$ 's speech to avoid liability. The offending speech may be defamatory, obscene, fraudulent, or a violation of copyright. In most situations $A$ has greater incentives to censor $B$

unreasonable failure to use any complaint procedure provided by the employer, a demonstration of such failure will normally suffice to satisfy the employer's burden under the second element of the defense. No affirmative defense is available, however, when the supervisor's harassment culminates in a tangible employment action, such as discharge, demotion, or undesirable reassignment.

Burlington Indus., 524 U.S. at 765 (citation omitted).

11. See Faragher, 524 U.S. at 799 (collecting cases); see also Sexual Harassment, 29 C.F.R. $\S 1604.11(\mathrm{~d})$ (1998) (EEOC Guidelines applying negligence standard).

12. Employers are not completely free to censor employee speech, of course; they are also constrained by wrongful discharge law, union rules, and civil service regulations.

13. See Browne, Title VII as Censorship, supra note 1, at 505, 510-13; Volokh, Freedom of Speech, supra note 1, at 1809-14; Volokh, What Speech, supra note 1, at 635-37.

14. I borrow this term from Michael I. Meyerson, Authors, Editors, and Uncommon Carriers: Identifying the "Speaker" Within the New Media, 71 Notre Dame L. Rev. 79, 116, 118 (1995). 
than $B$ has to self-censor. That is because $B$ has an additional interest in promoting his or her own speech that $A$ usually lacks. Hence $A$ can be expected to censor $B$ collaterally with little regard for the value of $B$ 's speech to $B$ or to society at large.

Although to my knowledge no court has yet recognized collateral censorship as a distinct doctrinal category, it appears to be a fairly common phenomenon. For example, editors and publishers, driven by fear of defamation suits, may refuse to run stories by their reporters. Internet service providers, fearing that they may be held liable for contributory infringement of copyrighted materials, may attempt to ban messages from parties suspected of disseminating such materials.

Once one recognizes the ubiquity of the phenomenon, it should be obvious that not all government regulation that leads to collateral censorship is unconstitutional. The question is which varieties are permissible and which are not. It is tempting but incorrect to argue that collateral censorship is never unconstitutional because there is no state action. It is not the state that is censoring the employee or the customer but a private party-the newspaper or the Internet service provider. In fact, there is state action in every case of collateral censorship, because the government has created incentives for private parties to censor each other. Moreover, in virtually all cases of collateral censorship, the government not only knows but expects and desires that the private party will censor the unprotected offending material, even if it does not know exactly how much constitutionally protected material will also be censored in the process. ${ }^{15}$

Even so, collateral censorship is not necessarily unconstitutional. For example, the editors and the publishers of the New York Times are liable for publishing defamatory articles written by their reporters. Hence editors and publishers of large metropolitan dailies like the New York Times exercise considerable oversight over their reporters' stories in order to avoid liability or the costs of defending a defamation lawsuit. Often acting on the advice of attorneys, editors and publishers severely edit or even discard much of what their reporters produce, even when a reporter insists that a story is accurate. The reporter's statements may be matters of intense public concern and core political speech. They may be constitutionally protected so that the government could not impose liability for them directly. Nevertheless, reporters who insist on writing what the

15. See Browne, Title VII as Censorship, supra note 1, at 510-13 (arguing that state action requirement is satisfied when employers censor employees); Volokh, Freedom of Speech, supra note 1, at 1816-18 (arguing that state action exists when employers create anti-harassment policies out of fear of government liability, but not if they create the same policies for other reasons). 
editor or publisher forbids out of fear of possible liability may be disciplined or even fired.

Do such limitations on employee speech violate the First Amendment? First Amendment law clearly does recognize constitutional limitations on liability for defamation, embodied in cases like New York Times Co. v. Sullivan, ${ }^{16}$ Gertz v. Robert Welch, Inc., ${ }^{17}$ and their progeny. One reason for these limitations is the fear that valuable speech will be chilled by liability for defamation. But the doctrines do not appear to make any distinction between chilling the speech of editors and publishers and chilling the speech of their employees, the reporters. Both reporters and editors are entitled to the same constitutional privilege. Indeed, in Cantrell v. Forest City Publishing Co., the Court approved of a jury charge which permitted the imposition of vicarious liability upon a publisher for the knowing falsehoods written by its staff writer. ${ }^{18}$ Here, in effect, the Court allowed the jury to hold the publisher strictly liable for an employee's defamation. Such a rule clearly gives a publisher strong incentives to censor employee speech. Yet the Court found no constitutional problem with applying the traditional doctrines of respondeat superior in this context. ${ }^{19}$

Federal securities laws require investment houses, brokerage firms, investment advisors, and even corporate officials to avoid making misleading statements about company profits, securities, and related investments. Companies are strictly regulated concerning what they may say about these matters, particularly in highly regulated procedures like proxy contests. ${ }^{20}$ Statements made by their employees, even politically motivated statements, may subject them to liability. Thus, rational companies will often severely limit the kinds of public statements their employees may make, and discipline or terminate employees who disobey. Do such rules violate the First Amendment because they chill the speech, not of the organizations

16. 376 U.S. 254, 283 (1964) (holding that First Amendment requires proof of actual malice in libel actions brought by public officials against critics of their official conduct).

17. 418 U.S. 323, 350 (1974) (extending New York Times rule to punitive damages sought by private figures).

18. 419 U.S. 245, 253-54 (1974).

19. See id. Employers could argue for a stronger and additional privilege to void the libel laws on the grounds that fear of liability forces them to silence their employees more than they would silence themselves. For example, a newspaper might argue that defamatory statements against private figures should be held to an actual malice standard rather than the negligence standard permitted by Gertz, because newspapers will be likely to censor their employees much more severely than they would censor their own speech under the negligence standard. There is no indication, however, that the Court applies a different standard for employers who publish the speech of their employees and employers (or other persons) who publish their own speech.

20. See generally Burt Neuborne, The First Amendment and Government Regulation of Capital Markets, 55 Brook. L. Rev. 5 (1989) (discussing the SEC's regulation of false and misleading speech about capital formation). 
themselves, but of their employees?

My sense is that neither of these situations presents a serious First Amendment problem, even though both involve collateral censorship. But this simply raises the question of when collateral censorship is constitutional, and when it is constitutionally troublesome.

The question we should ask is whether it makes sense, given the purposes of a regulatory regime, and the kind of harm that the legislature has a right to prevent, to treat the private censor and the private speaker as the "same speaker" for purposes of First Amendment law. Clearly this judgment is a legal fiction. The two speakers are not really identical, but the law is entitled to treat them as if they were one, and to hold the first liable for what the second does. The claim that the censor and speaker are the "same speaker" is just a shorthand way of saying that the private censor (the employer) has the right to control the content of the speaker's (the employee's) speech and that the private censor is properly responsible for the harmful effects of that speech.

Why might it be permissible to hold one speaker liable for the harms of another? One reason is that the private censor and speaker are part of the same enterprise that produces speech-related harm: They either collectively produce a single product that causes harm (a libelous publication), or their collective efforts create a harm or a risk of harm (misleading or fraudulent information about investments). A second reason is that the private censor is in the best position to avoid the harm. For example, we might think that the private censor is particularly good at distinguishing protected from unprotected harmful speech, that the private censor can avoid harms more easily and effectively than the speaker, or that the private censor has better information than the speaker.

Thus, we can identify three considerations that justify treating the private censor and the speaker as "the same speaker": (1) the private censor's right to control the speech of the private speaker, (2) the joint or collective production of a harm or danger of harm, and (3) the private censor's superior ability to avoid the harm. Not surprisingly, these reasons for treating the private censor and the speaker as "the same speaker" for purposes of First Amendment law resemble traditional justifications for vicarious liability, in which courts treat employer and employee as the "same tortfeasor" for purposes of liability. ${ }^{21}$ (They also suggest why the Court found little difficulty with the application of respondeat superior in Cantrell, even though the use of that rule in the defamation context clearly

21. See W. Page Keeton et al., Prosser and Keeton on the Law of Torts $\S 69$, at 499-501 (5th ed. 1984) (describing standard justifications for respondeat superior liability). 
chills the speech of reporters.)

It is easy to see why the justifications for vicarious liability are relevant to the constitutionality of collateral censorship. If we hold the private censor responsible for the private speaker's harmful speech, it is reasonable to expect the private censor to censor. Conversely, if we don't want to encourage the private censor to censor (because we value the free flow of ideas), we should ensure that the private censor is not held responsible for the private speaker's harmful speech. Thus, collateral censorship is most acceptable from a First Amendment standpoint when vicarious liability is most acceptable, and it is least acceptable from a First Amendment standpoint when vicarious liability is least acceptable.

Moreover, these three considerations - the private censor's right to edit and control content, the joint production of the harm by censor and speaker, and the private censor's superior ability to avoid the harm-help explain why collateral censorship does not seem to violate the First Amendment even when the censor and speaker are not employer and employee, or part of the same business enterprise. Take the case of authors and publishing houses, for example. Book publishers employ legal staffs to inspect author manuscripts for possible liability for defamation, fraud, or copyright infringement. Publishers do so because they will suffer the consequences of their authors' violations of the law. As a result, publishers often demand that authors rewrite or even omit troublesome passages as a condition of publication. No one doubts that these practices affect authors' practical ability to speak. But this collateral censorship does not violate their First Amendment rights, even when they engage in explicitly political speech. If defamation laws are constitutional with respect to suits against the author directly, they are also constitutional with respect to suits against the publisher, even though the publisher clearly has different incentives from those of the author and therefore will exercise collateral censorship in situations where the author would not self-censor.

Thus, the case of the author and publisher is much like that of the reporter and the editor. Like the newspaper editor, the book publisher possesses and exercises the right to editorial control over how authors express themselves. This editorial control over content is the price that reporters or authors must pay if they want to publish in a particular newspaper or in a book produced by a particular publisher.

Conversely, collateral censorship seems to pose the greatest constitutional problems when it is most troublesome to treat the censor and the speaker as the "same speaker" for First Amendment purposes. The most obvious example occurs when courts and legislatures impose liability for harmful speech on a distributor, a 
common carrier, or some other conduit that is not part of the same business enterprise as the censored speaker, lacks the right to exercise editorial control, and lacks information about the nature of the content flowing through its channels.

In fact, the one Supreme Court case that comes closest to recognizing the problem of collateral censorship seems premised on this distinction. In Smith v. California, ${ }^{22}$ a California statute made it a crime for bookstore owners to stock books that were later judicially determined to be obscene, even if the owner did not know of the books' contents. The Supreme Court struck down the statute, arguing that "if the bookseller is criminally liable without knowledge of the contents ... he will tend to restrict the books he sells to those he has inspected; and thus the State will have imposed a restriction upon the distribution of constitutionally protected as well as obscene literature."23 Hence, "[t]he bookseller's self-censorship, compelled by the State, would be a censorship affecting the whole public, hardly less virulent for being privately administered." 24 What the Court calls "self-censorship" in Smith is actually collateral censorship that arises from the different incentives of the bookseller and the book author. ${ }^{25}$ In Smith the Court saw through (or, more correctly, did not even notice) the state action objection that a private party was doing the censoring. ${ }^{26}$

Note that the Supreme Court suggested that it was unfair to hold the bookstore owner liable because the bookstore owner lacked information about the content of each and every book. This injustice is not merely unfairness to the individual bookseller. Nor is it purely a concern about inefficient sorting. If our only concern were keeping harmful speech out of bookstores, we could accept a blunderbuss approach. But in the First Amendment area we should be as concerned with false positives (non-obscene books that don't get stocked) as with false negatives (obscene books that wind up on the bookstore shelves). We should be concerned about closing off means of expression to the authors on the one hand, and closing off information to audiences on the other. That is why it is a bad idea, from a First Amendment perspective, to squeeze the distributor (such as a bookstore owner or a common carrier) in the middle. Concerns about mismatched incentives and inadequate information lie at the

22. 361 U.S. 147 (1959).

23. Id. at 153 .

24. Id. at 154

25. See Meyerson, supra note 14 , at 118 n.259.

26. This may be due to the fact that the Court describes the phenomenon as "selfcensorship." Because of the state statute, the bookstore owner cannot sell the books he or she might otherwise want to. But the most serious form of censorship is actually the censorship of the book's author and publisher, not of the bookstore, which acts mostly as a distributor or conduit for the censored speech. 
heart of the constitutional objection to collateral censorship.

The common law of defamation features similar policy concerns about collateral censorship, although the courts do not use the term and the relevant doctrines are not constitutionalized. The law of defamation recognizes the problem of collateral censorship through what is called the distributor's privilege. Generally speaking, a person who repeats a defamatory statement is as liable for publication as the original speaker (assuming the person also acts with the requisite degree of fault). ${ }^{27}$ However, a distributor of information, such as a newsstand or a bookstore, is generally not held to this standard unless the distributor knows of the publication's defamatory content. ${ }^{28}$ The fear is that if distributors were held to be publishers, distributors might restrict the kinds of books and magazines they sold, greatly reducing the public's access to protected expression.

To receive the common law privilege, a distributor does not have to be a common carrier, which must take on all customers without oversight. $^{29}$ Although distributors make some content-based judgments-for example, in choosing what books or magazines to stock-their editorial control is very different from and much more limited than that of the book publisher or magazine editor.

In the telecommunications industry, collateral censorship poses a genuine and recurrent constitutional problem: Cable companies and Internet service providers regularly act as conduits for the speech of unrelated parties. Treating them like publishers or editors would have the predictable effects noted above. ${ }^{30}$ Thus, in the

27. See Restatement (Second) of Torts $§ 578$ (1977) ("Except as to those who only deliver or transmit defamation published by a third person, one who repeats or otherwise republishes defamatory matter is subject to liability as if he had originally published it.").

28. See id. $\S 581$ (“' $[\mathrm{O}]$ ne who ... delivers or transmits defamatory matter published by a third person is subject to liability if, but only if, he knows or has reason to know of its defamatory character.").

29. A fortiori, telecommunications companies that act as common carriers receive the distributor's privilege. See id. $§ 581 \mathrm{cmt}$. f; see also Anderson v. New York Tel. Co., 320 N.E.2d 647 (N.Y. 1974) (holding telephone company not liable for defamation delivered across telephone lines).

30. Indeed, the argument for distributor privileges or other forms of reduced liability has regularly been made in cyberspace, because Internet service providers and computer bulletin boards are unable to supervise the content that flows through them. See, e.g., James Boyle, Intellectual Property Policy Online: A Young Person's Guide, 10 Harv. J.L. \& Tech. 47, 103 (1996); David J. Conner, Cubby v. Compuserve, Defamation Law on the Electronic Frontier, 2 Geo. Mason Indep. L. Rev. 227 (1993); Meyerson, supra note 14; Henry H. Perritt, Jr., Tort Liability, the First Amendment, and Equal Access to Electronic Networks, 5 Harv. J.L. \& Tech. 65, 106-08 (1992); Robert Charles, Note, Computer Bulletin Boards and Defamation: Who Should Be Liable? Under What Standard?, 2 J.L. \& Tech. 121, 145-50 (1987); Philip H. Miller, Note, New Technology, Old Problem: Determining the First Amendment Status of Electronic Information Services, 61 Fordham L. Rev. 1147, 1197-1201 (1993); see also Religious Tech. Ctr. 
Telecommunications Act of 1996, Congress extended a special privilege to Internet service providers whose customers post indecent, obscene, or "otherwise objectionable" matter in cyberspace, declaring that, as a matter of law, they should not be considered the publishers of such material. ${ }^{31}$

Hostile environment law surely produces collateral censorship. But the collateral censorship does not involve a distributor or conduit relationship. I believe that the employer who censors employees for fear of creating a hostile environment is more like the employer who censors employees out of fear of liability for defamation or securities fraud, and less like the Internet service provider who censors his or her customers, or the bookstore owner who refuses to stock certain books in order to avoid liability.

Unlike the case of the bookseller and the author, the employer and employee in a hostile environment case are part of the same business enterprise, and the employer has the contractual right to control the employee's speech and conduct. Perhaps more important, the law has good reasons to hold the employer accountable for the acts of its employees. First, the employer is better able to see the larger picture about what conduct might contribute to sex discrimination. This is especially so given that hostile environments emerge from a combination of behaviors that not all employees may have knowledge of. Second, and for similar reasons, the employer is also better able than individual employees to prevent hostile environments from emerging, especially when they result from collective actions that no individual employee may be able or willing to prevent.

Third, precisely because the creation of a hostile environment does not stem from any single act, but from many acts taken together, it makes sense to treat the harm to equal opportunity in the workplace as a single harm. Indeed, because collective action problems may reduce the ability or the incentives of individual employees to prevent hostile environments, it may make even more sense to treat employer and employees as a "single speaker" engaged in a single harm than it does in the case of defamation or securities

v. Netcom On-Line Communication Serv., Inc., 907 F. Supp. 1361, 1377-78 (N.D. Cal. 1995) ("If Usenet servers were responsible for screening all messages coming through their systems, this could have a serious chilling effect on what some say may turn out to be the best public forum for free speech yet devised.").

31. 47 U.S.C. § 230(c)(1) (Supp. II 1996); see Blumenthal v. Drudge, 992 F. Supp. 44, 4952 (D.D.C. 1998). In fact, the 1996 Act gives Internet service providers more protection than the traditional distributor's privilege, because knowledge of defamatory content is not sufficient to subject them to liability. See Zeran v. America Online, 129 F.3d 327, 331-32 (4th Cir. 1997), cert. denied, 524 U.S. 937 (1998). 
fraud. ${ }^{32}$

Fourth, the employer faces incentives to acquiesce in hostile environments that have no analogue in defamation or securities fraud situations. This makes the case for employer liability-and the need for incentives to police employees-even stronger. Sexual harassment is a form of sex discrimination that works to keep jobs and employment opportunities sex-segregated according to traditional gender roles-for example, by keeping women out of higher-paying construction positions and in lower-paying secretarial positions, or by imposing obstacles to advancement for women even in integrated workforces. ${ }^{33}$ Employers may accept (or ignore) sex discrimination by their male employees (including discrimination through sexual harassment) in order to avoid labor disruption and preserve esprit de corps and loyalty among a particular class of valuable (male) workers.

Why would employers acquiesce in sexual harassment by their male employees even if employers had no particular bias against women? In theory, employers could save money by staffing jobs with less well-paid women rather than with men, but this move might produce enormous labor disruptions, even with non-unionized workers. Under these conditions, acquiescence in labor segregation and reduction of employment opportunities to women is a secondbest solution to maximizing profits. Employers will accept a sexsegregated workforce with only a few token women in "male" positions (enforced by many different forms of sex discrimination, including employee harassment) as a compromise with existing male employees who want to maintain higher wages and workplace status. ${ }^{34}$

In short, the different incentives of employers and employees may push them toward a common strategy. Together the employer and the employees create an undifferentiated "product"-a workplace culture that distributes job opportunities by sex and

32. The argument for the constitutionality of collateral censorship in hostile environment cases is in some ways even stronger than in defamation and securities fraud cases because most courts currently hold the employer liable only if the employer knows or should have known of the harassment and does not take prompt corrective action. See supra text accompanying note 11. In other words, employers are not held strictly liable for employee speech (as in other vicarious liability situations) but are only liable when they fail to exercise due care in rooting out and remedying hostile environments. Hence the degree of collateral censorship should, in theory, be less in these cases.

33. For an account of the connections between hostile environments and job segregation in the workplace, see Vicki Schultz, Reconceptualizing Sexual Harassment, 107 Yale L.J. 1683, 1756-61 (1998). As Schultz points out, "[h]ostile work environment harassment is an endemic feature of the workplace that is both engendered by, and further entrenches, the sex segregation of work." Id. at 1760.

34. I am indebted to Vicki Schultz for this argument. 
enforces this result through subtle and not-so-subtle forms of discrimination and harassment. Together the employer and employees construct the opportunity that women have in the workplace, creating a single, undifferentiated harm to workplace opportunity.

Congress has a right to prevent this result. Title VII gives women and minorities an equal right to pursue work and an equal right to workplace opportunities. Through Title VII, Congress and the courts have imposed on all employers an obligation to guarantee their employees a workplace free from sexual discrimination and harassment, whether caused by managers or by co-workers-just as OSHA regulations require employers to guarantee a workplace free from defective health and safety conditions caused by management or by co-workers. Employers must take steps to achieve nondiscriminatory workplaces, and this includes restricting employee speech and behavior that contribute to a hostile working environment. In effect, Congress has required employers to produce a certain kind of business culture in the workplace. The Supreme Court's recent decisions in Ellerth and Faragher confirm this: Employers are strongly encouraged to create anti-harassment policies and complaint procedures as methods of monitoring their workers. ${ }^{35}$ The speech and behavior of individual employees is integral to the production of that culture, and the employer is in the best position to manage that culture, just as the employers have always managed business culture before the application of antidiscrimination laws.

In short, the problem of collateral censorship is really a question of the justifications for vicarious liability for speech acts. Because there are abundant good reasons to hold employers liable for employees' creation of a hostile environment, the collateral censorship produced by Title VII does not offend the First Amendment.

\section{CAPtive Audiences: The Hostile EnVIRONMENT AS A Mechanism OF JOB SEGREGATION}

Even though hostile environment law does not involve unconstitutional collateral censorship, critics have raised other, more radical First Amendment objections. These fall into three basic categories. First, the courts' standard of abusive conduct is unduly vague. Second, sexual harassment doctrines are overbroad because they prohibit speech that would clearly be protected outside the workplace. Third, sexual harassment doctrines make distinctions on

35. See Burlington Indus. v. Ellerth, 524 U.S. 742, 765 (1998); Faragher v. City of Boca Raton, 524 U.S. 775, 808-09 (1998). 
the basis of content and viewpoint. On closer inspection, however, none of these objections prove fatal.

The vagueness argument proves entirely too much: It applies equally to most judge-made communications torts. For example, speech is defamatory "if it tends ... to lower [an individual] in the estimation of the community or to deter third persons from associating or dealing with him." 36 Intentional infliction of emotional distress requires words or conduct "so outrageous in character, and so extreme in degree, as to go beyond all possible bounds of decency, and to be regarded as atrocious, and utterly intolerable in a civilized community... [where] recitation of the facts to an average member of the community would arouse his resentment against the actor, and lead him to exclaim, "Outrageous!'"37 A judicial standard that requires severe or pervasive intimidation, ridicule, insult, and abuse does not seem unduly vague in comparison with these torts. In fact, much of the objection to the vagueness of hostile environment doctrine seems directed at the worry that employers will collaterally censor employees. Collateral censorship will certainly occur, but it does not make hostile environment law unconstitutional, any more than it makes defamation or securities fraud law unconstitutional.

The second argument- that harassing speech would be protected outside of the workplace-is more promising. But it, too, proves unavailing. Often speech that would be protected in the public square becomes unprotected when it occurs in special social situations involving special social roles. If a White House intern sleeps with the President and falsely denies it at a press conference, her false statement is protected. However, if she repeats the same denial in an affidavit or on the witness stand, she can be prosecuted for perjury. The same words inserted into a new social context create different responsibilities and different degrees of First Amendment protection.

Sexually harassing speech that would be protected outside of the workplace becomes unprotected within it because it occurs in a particular relationship of economic and social dependence-the employment relation-and because it involves a form of sex discrimination that (1) materially alters the terms and conditions of employment for women, (2) reinforces the lower status of women in employment relationships, and (3) preserves gender stratification in employment markets. In short, like perjurious statements, speech used to create a hostile working environment is unprotected not because of its content, but because in the social context in which it

36. Restatement (Second) of Torts $\S 559$ (1977).

37. Id. $\S 46 \mathrm{cmt}$. d. 
occurs, it is used as a method of employment discrimination. To understand why this is so, we must consider the purposes of employment discrimination law in more detail.

Employment discrimination law protects multiple interests. It prevents harms to material or economic interests like salary and working conditions. But it is also concerned with the social status of groups; it attempts to dismantle unjust forms of social stratification in the workplace that are visited upon individual people. These two concerns are intimately connected. Social stratification both within and outside of the workplace is often reflected in workplace arrangements that give some people greater material advantages and economic opportunities than others. In addition, stratification within the workplace helps reproduce the social status and material disadvantages of groups in the larger society: The structure of the workplace helps reinforce the social meanings of superiority and inferiority that attach to being white or black, male or female. ${ }^{38}$

Title VII's prohibition against sexual harassment is a prohibition of a particular mechanism of sex discrimination. It must be read in light of Title VII's larger purposes. It would be a great mistake to understand hostile environment doctrine simply as a set of rules designed to preserve civility, to protect individual dignity, or to prevent offense. Sexual harassment is prohibited because it is a status-enforcing mechanism-it employs offense, insult, and indignity to maintain the inferior status of women. Prohibitions on the use of this mechanism are designed to dismantle social subordination and to achieve civil equality, both within the workplace and, through their effects on the structure of work, in society as a whole.

Title VII protects against both material- and status-based harm because material and status elements are inextricably intertwined in the workplace, and cannot easily be separated. This should not be surprising: Common sense tells us that people with large corner offices do not receive lower salaries and reduced authority as a tradeoff, and people in cubicles don't get juicier work assignments as compensation. Rather, people with high status and esteem usually also enjoy better salaries and working conditions. Conversely,

38. As Vicki Schultz explains:

[M]en's advantage in numerous spheres of life depends on their superior status in the workplace; men's status as superior wage earners and possessors of masculine work competence is also central to mainstream definitions of masculinity. Thus, it serves men's interests to monopolize the most highly rewarded forms of work for themselves, and hostile work environment harassment provides a mechanism for doing so. In this analysis, wage work and work relations are not mere reflectors of gendered roles created elsewhere; they are important institutions for reproducing both gender inequality and gender identity.

Schultz, supra note 33, at 1761 n.409. 
people lower in the hierarchy of the workplace usually enjoy lesspleasant working conditions and lower compensation.

Because material benefits and social status are so deeply interconnected in the workplace, status-based harms that significantly alter people's working conditions for the worse constitute employment discrimination under Title VII. That is why there is nothing particularly unusual or special about hostile environment liability. Hostile environment situations are just a special case of ordinary disparate treatment discrimination: They are harms to employees' group status-imposed on account of their membership in the group-that materially alter their working conditions as individuals and, in the process, also reinforce the social status of the group. ${ }^{39}$

People also reproduce group status distinctions outside the workplace; for example, they engage in racist or misogynist speech or other speech that perpetuates racial or gender stereotypes. But the First Amendment generally does not permit recovery for these harms to group status. ${ }^{40}$ The First Amendment does permit recovery for defamation, but largely for injury to individual reputation rather than harm to group status. ${ }^{41}$

In the workplace, however, the First Amendment does allow people to recover for harms to group status when (and only when) such harms so materially alter workplace conditions that they constitute employment discrimination under Title VII. The test of material alteration is the test of Harris v. Forklift Systems, Inc. and Meritor Savings Bank v. Vinson: The plaintiff must face a workplace

39. To be sure, some elements of hostile environments are not specifically directed at women and minorities but nevertheless effectively deny them equal opportunity in the workplace. These elements should be regarded as special cases of disparate impact discrimination, i.e., they involve business conditions and business decisions that have a disparate impact on women and minorities but are not justified by any business necessity.

40. This is implicit in the Supreme Court's equation of speech producing these harms in the public sphere with speech producing other varieties of offensiveness. See R.A.V. v. City of St. Paul, 505 U.S. 377, 391-92 (1992) (arguing that the First Amendment protects both hate speech directed at Catholics and anti-Catholic bigots); see also Texas v. Johnson, 491 U.S. 397, 414 (1989) ("If there is a bedrock principle underlying the First Amendment, it is that the government may not prohibit the expression of an idea simply because society finds the idea itself offensive or disagreeable."). The First Amendment may permit recovery for "fighting words," or for intentional infliction of emotional distress, see Chaplinsky v. New Hampshire, 315 U.S. 568, 571-72 (1942), but these categories are very limited and do not include all or even most racist or misogynist speech.

41. Compare Gertz v. Robert Welch, Inc. 418 U.S. 323, 341 (1974) (discussing compelling interest in protecting individual reputation), with Beauharnais v. Illinois, 343 U.S. 250, 263-64 (1952) (upholding group libel statute). Beauharnais has never been overruled but its precedential value is generally thought doubtful, especially after New York Times Co. v. Sullivan, 376 U.S. 254 (1964), and R.A.V. See Laurence H. Tribe, American Constitutional Law $\S 12-12$, at $861 \mathrm{n} .2$, $\S 12-17$, at $921 \mathrm{n} .9, \S 12-17$, at $926-27$ (2d ed. 1988). 
"permeated with 'discriminatory intimidation, ridicule, and insult' that is "sufficiently severe or pervasive to alter the conditions of the victim's employment and create an abusive working environment" as judged by a reasonable person. ${ }^{42}$ The harms that a plaintiff suffers in these situations are harms of group subordination and employment discrimination; producing these harms is how subordination and discrimination are performed. Just as false speech before a jury is punishable not merely because it is false but because false speech in this setting is perjury, status-based harms in the workplace are sanctionable not merely because they are offensive or affronts to one's dignity but because harms in this setting are mechanisms of employment discrimination. They are forms of disparate treatment that help sustain job segregation in the workplace.

The method of employment discrimination we are concerned with here operates by surrounding the worker in a hostile or abusive environment that he or she cannot easily escape; hence the term "hostile environment" liability. Recognizing how employment discrimination works through the creation of a hostile environment helps us understand the connection between the underlying purposes of Title VII-combating stratification and status reinforcement in the workplace - and the doctrines of the First Amendment, which permit content-based regulation to protect "captive audiences." Simply put, a person trapped in a hostile work environment is a "captive audience" for First Amendment purposes with respect to the speech and conduct that produce the discrimination. Put another way, hostile environments do the work of job segregation by making workers captive audiences. Although courts created the captive audience doctrine for other situations, it actually makes better sense in the context of the workplace. ${ }^{43}$ Indeed, I shall now argue that this

42. Harris v. Forklift Sys., Inc., 510 U.S. 17, 21 (1993) (quoting Meritor Sav. Bank v. Vinson, 477 U.S. 57, 65, 67 (1986)). It is important to emphasize that the law of sexual harassment requires a relatively high threshold of emotional, dignitary, or other status-based harm before the plaintiff states a valid claim that employment conditions have been materially altered in violation of Title VII. A high threshold is probably constitutionally necessary. However, as the Court pointed out in Harris, it need not constitute intentional infliction of emotional distress. See id. at 21-23.

43. See J.M. Balkin, Some Realism about Pluralism: Legal Realist Approaches to the First Amendment, 1990 Duke L.J. 375, 424:

I suggest that we might do well to shift the paradigmatic case of the captive audience from the passengers on the public buses or the child running through stations on the radio dial, to the employee working for low wages in a tight job market who is sexually harassed by her employer or co-worker.

See also Robinson v. Jacksonville Shipyards, Inc., 760 F. Supp. 1486, 1535 (M.D. Fla. 1991) ("female workers ... are a captive audience in relation to the speech that comprises the hostile work environment."); Richard H. Fallon, Jr., Sexual Harassment, Content Neutrality, and the First Amendment Dog That Didn't Bark, 1994 Sup. Ct. Rev. 1, 43 (noting that although courts have not done so, the case for extending captive audience designation to workplaces is strong); Suzanne Sangree, Title VII Prohibitions Against Hostile Environment Sexual Harassment and the 
doctrine is best understood through the lens of Title VII's purposes.

Generally speaking, people are captive audiences for First Amendment purposes when they are unavoidably and unfairly coerced into listening. According to the Supreme Court, the paradigmatic case of a captive audience involves assaultive speech directed at the home. ${ }^{44}$ The Court's other major example has been people riding on public buses who cannot avoid looking at political advertisements. ${ }^{45}$

Without further theorization, captive audience doctrine can be a troublesome idea. A broad reading of the captive audience doctrine "would effectively empower a majority to silence dissidents simply as a matter of personal predilections." 46 One could regulate offensive speech based on rather vague notions of captivity. Thus, it is not surprising that First Amendment scholars have tried to recast captive audience doctrine as really a doctrine limited to speech aimed at the home, where courts view privacy concerns as at their highest. ${ }^{47}$ So understood, the "captive audience" doctrine is not about captive audiences at all, but about the special nature of particular places like the home. ${ }^{48}$

I believe that the articulation of the captive audience doctrine by both courts and commentators has been mistaken. It is both overand underinclusive. There is nothing talismanic about the home for purposes of captivity. So-called captive audiences in the home can throw away junk mailings, change the dial, activate v-chips, operate

First Amendment: No Collision in Sight, 47 Rutgers L. Rev. 461, 515-18, 539-40 (1995) (defending captive audience analysis of workplace harassment); Marcy Strauss, Redefining the Captive Audience Doctrine, 19 Hastings Const. L.Q. 85, 89-103 (1991) (applying the doctrine to workplace harassment); Marcy Strauss, Sexist Speech in the Workplace, 25 Harv. C.R.-C.L. L. Rev. 1, 36 (1990) (arguing that employees "qualify for captive audience status").

44. See, e.g., Frisby v. Schultz, 487 U.S. 474, 487 (1988) (upholding ban on residential picketing directed at a single house); see also FCC v. Pacifica Found., 438 U.S. 726, 748-49 (1978) (upholding FCC sanctions for indecent broadcast against radio station playing George Carlin's "seven dirty words" monologue); Rowan v. United States Post Office Dep't, 397 U.S. 728, 737-38 (1970) (upholding Post Office provision that allowed individuals to specify to the Postmaster General certain sexually explicit mailings they did not wish to receive); Kovacs v. Cooper, 336 U.S. 77, 87 (1949) (upholding ban on sound trucks to protect residents).

45. See Lehman v. City of Shaker Heights, 418 U.S. 298, 301-04 (1974) (plurality opinion) (upholding ban of political advertising on public buses on grounds that passengers are a "captive audience").

46. Cohen v. California, 403 U.S. 15, 21 (1971).

47. See Fallon, supra note 43, at 18-19 (describing the Court's justification for these restrictions as based on the "special characteristics of the home"); Volokh, Freedom of Speech, supra note 1, at 1832-33 (arguing that the doctrine is properly limited to the home).

48. See Fallon, supra note 43, at 18 ("When the so-called captive audience cases are read in conjunction, the character of the place seems more important than the degree of audience 'captivity' in explaining the applications of captive audience doctrine."); Volokh, Freedom of Speech, supra note 1, at 1833 (arguing that the Supreme Court has never upheld a captive audience justification for content-based restrictions outside of the home). 
the channel blocking capabilities of cable boxes, install filtering software, or, if all else fails, disconnect the cable service, turn off the television, and stop subscribing to an Internet service provider.

Nor is the home an unalloyed example of "privacy." In the Information Age, we increasingly receive information in our homes rather than in public spaces. New technologies like the Internet redraw and even collapse the boundaries between public and private spaces. One can participate in public discourse and public deliberation while sitting at the keyboard dressed in one's underwear. This was already true with respect to television; it is even more true in the case of interactive media like the Internet. In most cases the protection of children and parental control over children are much better justifications for regulation of content than captive audience doctrine. 49

Conversely, limiting captive audience situations to the home misses the point of the metaphor of captivity - that a person must listen to speech because he or she is practically unable to leave. Children may be subject to discipline in the home, but for most adults, the place they are most subject to the discipline of others and least free to leave is at work. Economic coercion leaves many workers unable to avoid exposure to harassing speech. Employees are a much better example of a captive audience than the so-called paradigm case of people sitting in their homes.

Captivity in this sense is a matter of practicality rather than necessity. It is about the right not to have to flee rather than the inability to flee. The Supreme Court has suggested that people riding in buses subjected to political advertisements were a captive audience; but surely these people could have chosen other forms of transportation albeit at greater expense and inconvenience. Even people in their homes are not physically prevented from leaving them. The point of captive audience doctrine, however, is that they should not have to be put to such a choice. The coercion brought upon them is unfair. In like fashion, minimum wage workers may have to move from job to job to avoid harassment. But the question is not whether there is another equally low-paying job available. The question is whether they should have to leave a job to avoid being sexually harassed. ${ }^{50}$ It would undermine the central purpose of Title

49. See J.M. Balkin, Media Filters, the V-Chip, and the Foundations of Broadcast Regulation, 45 Duke L.J. 1131, 1137-39 (1996).

50. Vicki Schultz has described the "revolving door" phenomenon of women in low paying jobs who are continually forced to change jobs because of sex discrimination or harassment. See Vicki Schultz, Telling Stories about Women and Work: Judicial Interpretations of Sex Segregation in the Workplace in Title VII Cases Raising the Lack of Interest Argument, 103 Harv. L. Rev. 1749, 1826 n.287, 1839 (1990). These women find themselves on a perpetual exodus from jobs that are "a dime a dozen." The phenomenon of these forced exits is not an 
VII to argue that it gave workers no right to stay in a job free from sexual harassment. Moreover, as noted before, the kind of employment discrimination at issue here promotes gender segregation in job opportunities precisely by surrounding the plaintiff in a hostile environment of speech and conduct. If the plaintiff's only remedy is to leave, the mechanisms of job segregation will simply proceed unabated.

Captive audience doctrine should not focus on particular spaces like the home. Rather, it should regulate particular situations where people are particularly subject to unjust and intolerable harassment and coercion. Captive audience doctrine, like the doctrines of Fourth Amendment privacy, should protect people in coercive situations, not places. 51 "The workplace" is not a place; it is a set of social relations of power and privilege, which may or may not have a distinct geographical nexus. If a male supervisor makes an obscene phone call from his home to a female subordinate in a hotel room, this unwelcome behavior can and should contribute to a hostile work environment, even though both supervisor and subordinate are miles away from the office. Geographical proximity may be relevant to our judgments of the unreasonableness of a practice and the discomfort produced by it, but it is hardly necessary to achieve sex discrimination. As the workplace becomes more and more mediated by e-mail and the Internet, the geographical conception of captive audience doctrine will become increasingly unwieldy. The telecommunications revolution we are currently undergoing should help us recognize that what is at stake are social relations of power and dependence which, for convenience, we identify with a geographical metaphor. ${ }^{52}$

The practical necessities of earning a living and the economic coercion inherent in the social relations of the workplace create captive audience situations; but this does not mean that the workplace itself should be treated as a First Amendment-free zone. In fact, the workplace should be an arena of special, not lessened,

argument against the application of captive audience doctrine to harassment law; it is an argument for it.

51. Cf. Katz v. United States, 389 U.S. 347, 351 (1967) (holding that the Fourth Amendment "protects people, not places").

52. Deborah Epstein emphasizes the physical context of the workplace as important to captive audience doctrine. She reports that she can find no example of a post-Vinson case in which communications outside the workplace contributed to a hostile environment finding. See Deborah Epstein, Can a "Dumb Ass Woman" Achieve Equality in the Workplace? Running the Gauntlet of Hostile Environment Harassing Speech, 84 Geo. L.J. 399, 421-23 \& n.128 (1996). But cf. Bundy v. Jackson, 641 F.2d 934, 940 n.2 (D.C. Cir. 1981) (pre-Vinson case in which supervisor's call to employee at her home was part of hostile environment in conjunction with other abusive speech at workplace). Of course, the problem is what we will consider the workplace to be as more and more people work in geographically separated places. 
free speech protection. Precisely because people spend so much of their lives in the workplace, the workplace is an important site of public discourse. ${ }^{53}$ Much employee speech in the workplace is not, nor should it be considered, exclusively "managerial," "instrumental," or "private." We may talk more about public matters, sports, gossip, politics, and the affairs of the day at our workplace than we do at home. The problem with existing employment law is that it gives employers too much power to control the speech of employees on every subject, not simply on matters of sex and sexuality.

One way of justifying sexual harassment liability in the workplace would be to make a categorical distinction between the world of public discourse and the world of the workplace. Thus, one might argue that "there are good reasons for the law to regard persons as autonomous within the context of political deliberation, but there are equally good reasons for the law to regard persons as dependent within the workplace." 54 However, because the workplace is also an important site of public discourse, the law cannot simply insist that workers are to be regarded as dependent in all their speech interactions in workplace settings. Otherwise, Congress could regulate virtually all workplace speech. Put in the language of captive audience doctrine, workers would be captive audiences for all purposes.

That is why it is important to understand that the basis of captive audience doctrine is social relations rather than geographical places. Sexual harassment is a form of sex discrimination that maintains sexual stratification and that occurs in the context of the economic dependency of work relations. Put another way, sexual harassment is a device through which sexual stratification of the workplace is achieved or maintained, using the economic dependency of workers as a powerful form of leverage. Thus, the law may regard workers as dependent and not autonomous with respect to speech that helps achieve or maintain such stratification, but not with respect to other speech.

Critics of hostile environment liability miss this point, I think, when they argue that "[h]arassment law, if viewed as an attempt to protect a captive audience, is ... underinclusive" because it only applies to speech that "creates a hostile environment based on race,

53. See Cynthia Estlund, Freedom of Expression in the Workplace and the Problem of Discriminatory Harassment, 75 Tex. L. Rev. 687, 717-18 (1997). Indeed, Kent Greenawalt argues that workers are "captive speakers," because they may have few other places to express themselves, and because "[w]hen people are working, the only place they can express themselves is within the workplace." Kent Greenawalt, Fighting Words 86 (1995) (emphasis omitted).

54. Robert C. Post, The Perils of Conceptualism: A Response to Professor Fallon, 103 Harv. L. Rev. 1744, 1746 (1990). 
sex, religion or national origin." 55 The point is precisely that people are almost never captive audiences for every purpose, even in the workplace. They are only captive audiences in the workplace with respect to certain forms of unjust coercion that use the employee's economic dependence as a springboard. Sex discrimination is one of those situations. Another is the use of economic coercion to prevent or hinder decisions about unionization, as illustrated in labor cases like NLRB v. Gissel Packing Co. ${ }^{56}$

In Gissel the Supreme Court upheld an NLRB order requiring an employer to bargain with a union that had lost an election. The election was held to be tainted by the employer's truthful statements that election of a union could lead to closing of the employer's plant or, if the union called a strike, to a transfer of operations. Professor Kingsley Browne, a critic of hostile environment liability, insists that "[t]he reasoning of Gissel does not support a general governmental right to regulate speech in the workplace." 57 I quite agree. Gissel holds only that when unfair employment practices make use of the coercion already inherent in the employment relationship-including practices involving truthful statements - the government may step in to regulate workplace speech in order to promote equality values. The same is true of captive audience doctrine as applied to the workplace. Captive audience doctrine is best understood as limited to employment situations where speech and conduct together will help perpetuate job segregation or other forms of employment discrimination that Congress has a right to prevent, just as in Gissel Congress had a right to prevent attempts to hinder employees from bargaining freely. ${ }^{58}$

In short, we should not confuse the economic dependence of employees with their ability to participate in public discourse about the things that matter to them. Precisely because workers are economically dependent within the workplace, but engage in public discourse there, Congress might want to make them more autonomous within the workplace by guaranteeing them certain speech rights against their employers. This means, for example, that political speech by employees should be exempted as a basis for hostile environment liability as a matter of statutory construction and that Congress might even want to take positive steps to protect such speech from retribution by employers. ${ }^{59}$

55. Volokh, Freedom of Speech, supra note 1, at 1843.

56. 395 U.S. 575 (1969).

57. Browne, Title VII as Censorship, supra note 1, at 514.

58. See Gissel, 395 U.S. at 618.

59. Political speech might be defined as speech intended to contribute to a discussion of public issues. The example that begins Professor Browne's article- "Women do not belong in the medical profession; they should stay home and make babies!"-would presumably qualify 
Clearly some political speech can help contribute to sexual stratification in the workplace, at least at the margins. But it is unlikely that in most cases it is the major contributor. Working through the facts of actual cases, one is more likely to find pranks, taunts, sexual suggestions, and personal invective than political agitation as the basic technology for creating hostile environments. ${ }^{60}$ Because political speech is valuable, and because it contributes only marginally to sexual stratification, courts should exempt it. ${ }^{61}$ Doing so may also ameliorate some of the effects of collateral censorship, because employers can be assured that they will not be held liable for explicit political rhetoric by their employees. ${ }^{62}$

Some commentators have tried to offer a distinction between directed and non-directed speech; that is, between speech specifically directed at a particular individual or a particular set of individuals (such as face-to-face insults), and speech that is not.63 Only the former can form the basis of hostile environment liability, while the latter is exempted. I think a better distinction is between "open" and "hidden" speech; that is, between speech that openly contributes to preserving sexual stratification-putting women in their place-and speech that is relegated to private consumption by willing participants or private conversation among willing listeners either at the workplace or away from it. Take the case of pornography, the classic example of non-directed speech. Employees who keep

under such an exemption if offered in a debate with a co-worker. Browne, Title VII as Censorship, supra note 1 , at 481 . Nevertheless, such a statement would certainly be evidence of intent to discriminate in a disparate treatment case if spoken by a supervisor and the person to whom it was spoken was subsequently denied a promotion.

Although I argue for exclusion of political speech as a matter of statutory construction in order to avoid potential constitutional difficulties, Kent Greenawalt takes a somewhat different approach. He has argued that we should make a distinction between a male construction worker who occasionally says to a female co-worker, "they should never have allowed women in these jobs," and one who repeatedly greets her with this slogan every morning, even after she complains that she is an unwilling listener. Greenawalt, supra note 53, at 90-91. Greenawalt argues that even such (arguably) political speech that contributes to public discourse could become part of a hostile environment in these situations, because we could properly infer that the speaker's intention was to harass or annoy rather than to express an opinion.

60. See Epstein, supra note 52, at 406-08 (describing recurring fact patterns in a number of cases).

61. Cf. Fallon, supra note 43, at 47 (arguing for a somewhat narrower exemption for speech “"reasonably designed or intended to contribute to reasoned debate on issues of public concern"”) (citing Harvard Law School's draft Guidelines Concerning Sexual Harassment).

62. Nevertheless, for reasons described below, employers may not take up this opportunity to lessen workplace speech rules.

63. See, e.g., Michael P. McDonald, Unfree Speech, 18 Harv. J.L. \& Pub. Pol'y 479, 485 (1995) ("Speech uttered that is not directed toward specific individuals should never be regulated as harassment."); Strossen, supra note 2, at 718 (noting importance of distinction between directed and non-directed expression); Volokh, Freedom of Speech, supra note 1, at 1846, 186869 (arguing that personal, directed, face-to-face insults and sexual propositions are regulable; non-directed speech, even if it cannot be avoided, is not regulable). 
pornography in their desk drawers out of sight should be distinguished from employees who keep pornography prominently displayed around the workplace where co-workers are likely to see it. Male employees who tell each other dirty jokes not intended to be overheard by female co-workers should be treated differently than employees who do so openly in order to distress and offend their female counterparts. The point is that some speech is not intended for general consumption, particularly speech that occurs out of public view and away from other co-workers. Employees can avoid exposure to this speech with relatively little effort and the burden should be on them to do so. Thus, as a matter of statutory construction, and in order to avoid constitutional problems, courts should not consider "hidden" or "non-public" speech between willing participants as constituting a hostile environment, even if it is not overtly political in character. The same should apply to "afterhours" speech and gossip between willing participants that is not intended to be overheard by co-workers. ${ }^{64}$

One reason why the open/hidden distinction is superior to the directed/non-directed distinction is that the former is more in keeping with the purposes of hostile environment liability. Recall that an individual employee's comment or expression may not by itself constitute a hostile environment, but many different acts taken together can. This makes sense because, from the perspective of the female or black employee, the hostility of environment is experienced as a whole, not in isolated bits. It is the environment as a whole - and the felt sense that women or minorities are poorly regarded or unwelcome in the workplace-that preserves or maintains sexual or racial stratification. Thus, the open/hidden distinction imagines the cumulative effect of expression from the perspective of the victim of the hostile environment, who experiences it as a gestalt. By contrast, the directed/non-directed distinction looks at the issue of hostile environment from the perspective of the individual perpetrator, who may well not understand how his or her non-directed expression contributes to an overall feeling of unwelcomeness or second-class citizenship.

64. Nevertheless, such speech might be evidence of sex discrimination, or of other speech or conduct that would constitute a hostile environment. The directed/non-directed distinction becomes more significant with respect to this latter question. If two male employees tell dirty jokes to each other out of earshot, that is not very probative of whether they are contributing to a hostile environment in other contexts. But if they tell dirty jokes about one of their female coworkers, that may well be relevant. E-mail provides a particularly good example. If two male employees send each other private e-mail messages describing a female movie star's particular charms in graphic detail, that is quite different from a discussion about one of their co-workers. Obviously many employers might wish to restrict or prohibit non-work-related discussions using company e-mail for any number of reasons, but certainly one is the possibility that such e-mail messages will later be used as evidence in a hostile environment case. 
Although commentators have made much of the distinction between directed and non-directed speech, this distinction will probably matter little to employees in practice, because of collateral censorship. Employers may well decide that pornography should be kept out of the workplace entirely, whether or not it is thrust in the face of unwilling co-workers; they may collaterally censor their employees from non-directed as well as directed speech as an extra precaution. But, as argued before, this collateral censorship is not unconstitutional.

There is thus a certain irony in advocating the directed/nondirected distinction and raising a collateral censorship objection, as critics of hostile environment liability sometimes do. If collateral censorship is really a constitutional problem, as the critics insist it is, it will not be eliminated by restricting liability to directed expression.

Indeed, I would go even further and argue that many employers may not even respect the open/hidden distinction fully in their policies. For example, it is entirely possible that many employers will choose to prohibit the private possession of pornography at work, even if it is kept hidden at all times. On the other hand, employers are much more likely to respect the open/hidden distinction in other ways: Employers might well decide that what employees say after hours or out of earshot of unwilling listeners on their lunch break is their own concern.

The final constitutional objection to hostile environment law is that its judge-made doctrines are content- and viewpoint-based. Once again, this proves too much: The same charge could be leveled against defamation, fraud, and most other communications torts. Juries in defamation cases are required to make content-based judgments about what kinds of statements would hold people up to shame or ridicule in the community and to assess damages based on the degree of injury to reputation. Moreover, liability for defamation clearly depends on viewpoint. If a defendant falsely says "Smith is a crook," she may be subject to liability, but not if she falsely says "Smith is an honest man."

If status-based harms are to be protected at all, some contentbased and even viewpoint-based distinctions are inevitable. As we have seen, Title VII appropriately protects workers from a limited class of status-based harms because protecting workers from these harms is essential to guaranteeing equality in the workplace. Thus, it makes perfect sense that a sign saying "Sarah is Employee of the Month" should not give rise to liability, while a sign reading "Sarah is a dumb-ass woman" 65 could form part of a hostile environment case. These content-based distinctions are adapted to the very reason 
why status-based or dignitary harms may be protected in the first place. ${ }^{66}$

\section{THE DEEPER ISSUE: EMPLOYER CONTROL}

Critics of sexual harassment law have offered many horror stories about employer censorship. Most of these involve employer decisions that are overzealous, reflect traditional or puritanical sexual mores at odds with Title VII's promise of sexual equality, are products of mindless bureaucracy, or are plain idiotic. 67 They have not been required either by the actual doctrines of Title VII or by prudent compliance policies. Nor is this surprising. By and large federal judges have been quite careful to limit liability for hostile environments to situations of severe or pervasive worker abuse. Indeed, feminist legal scholars have criticized judges for construing the law too narrowly. ${ }^{68}$

There is some irony in libertarian complaints about employees' freedom of speech. In America the state has generally offered very little protection for employee speech. The traditional common law rule has been that employees can be fired at will absent a contractual provision to the contrary; in other words, unless employees have sufficient bargaining power to demand "just cause" or other security provisions in their contract, the employer can sanction or fire them for virtually any reason, ${ }^{69}$ including displeasure with their speech, even their political speech. The common law regime is still the default rule today, and it provides employers with one of their most potent weapons for shaping the culture of the workplace and the behavior of their employees. American law is in marked contrast with that of many other countries. In Europe, for example,

66. Cf. R.A.V. v. City of St. Paul, 505 U.S. 377, 383 (1992) (arguing that content-based discrimination within a category of unprotected speech is justified when it furthers the purpose for which the speech is unprotected). Not surprisingly, even Professor Volokh drops his objections to content- and viewpoint-based restrictions on harassment when the harassment is directed at a particular person. See Volokh, Freedom of Speech, supra note 1, at 1866-67.

Note, moreover, that under the logic of R.A.V., Congress is permitted to limit recovery for harassment only for those forms of employment discrimination that it prohibits, but not for harassment based on other subjects or based on other elements of a person's identity. Hence, one may not argue that Title VII is unconstitutionally content-based because it does not cover harassment on all subjects, but only on the basis of race, sex, national origin, and religion. Congress is permitted to decide that discrimination on those grounds is more unjust, inflicts greater or more distinctive harms on its victims, or causes greater social problems than other forms of discrimination which it has chosen not to prohibit. See Wisconsin v. Mitchell, 508 U.S. 476, 487-88 (1993).

67. For a parade of horribles, see Volokh, What Speech, supra note 1, at 642-46.

68. See, e.g., Epstein, supra note 52, at 416-17 \& n.113 (noting that scope of judicial enforcement has been "narrow" and "excessively restrained").

69. See Cynthia L. Estlund, Free Speech and Due Process in the Workplace, 71 Ind. L. Rev. 101, 116-17 (1995). 
employees often enjoy more substantial rights against arbitrary discharge. ${ }^{70}$

Thus, sexual harassment doctrines do not pose a simple conflict between some employees' liberty and other employees' equality. The question is not whether employees will have freedom of speech, but how employers will control employee speech-whether they will do so in response to the incentives produced by Title VII or for their own purposes.

Blaming employee censorship on Title VII diverts our attention from a larger issue: Employers exercise considerable and sometimes tyrannical control over the speech and behavior of their employees. Throughout history American employers often have been deeply interested in control over their workers and in the culture of the workplace. They are no less interested than the government in inculcating social norms of appropriate speech and behavior. Often they go even further, imposing elaborate dress codes and rules of social etiquette. They seek to inculcate norms they believe will increase or sustain productivity. Employers tend to like employees who are "team players" and work for the good of the enterprise. They will even tolerate employee behavior that is racist, sexist, unjust, or anti-social, as long as it promotes workplace cohesion and morale and is not bad for business.

In fact, the most important counterweights to the employer's power to shape workplace culture through hiring and firing decisions are antidiscrimination laws. Without the incentives created by sexual harassment law, employees are simply remitted to the economic and social control of employers. In other words, First Amendment challenges to sexual harassment law are a defense of employer prerogatives presented in the guise of worker liberties.

In the long run, employers will not necessarily lose much control over the workplace because of sexual harassment law. To the contrary, compliance with government regulation is often not a danger but an opportunity. Employers will use sexual harassment law as a new device for controlling their subordinates, by combining legal compliance with other bureaucratic and economic goals. Many tales of unjust compliance practices can be understood in precisely this way. The excuse of sexual harassment liability allows employers to impose ever new controls on employee behavior during an age when employees are spending more and more time at work and tend to rely more and more on the workplace to meet their partners.

70. See, e.g., Frances Raday, Individual and Collective Dismissal-A Job Security Dichotomy, 10 Comp. Lab. L. 121, 132 (1989) (noting that many European countries recognize the right to job security as a fundamental employment right). 
When First Amendment challenges are raised to sexual harassment law, civil libertarians should not be diverted from the deeper issues of employer control and employee freedom. We can protect the First Amendment best by following the law as it is written-by awarding damages only in cases where severe or pervasive abuse materially alters employment conditions. But we should also not forget to protect employees - all employees-by working for greater speech rights against their employers than American law has seen fit to give them. For many employees, those are the speech rights that really count. 